\title{
Trend of Particulate Matter PM 2.5 and PM 10 in Dhaka City
}

\author{
M. A. Rouf*a, M. Nasiruddin ${ }^{\mathrm{b}}$, A. M. S. Hossain ${ }^{\mathrm{b}}$ and M. S. Islam ${ }^{\mathrm{a}}$ \\ ${ }^{a}$ Institute of Fuel Research and Development, BCSIR, Dr. Qudrat-I-Khuda Road, Dhanmondi, Dhaka-1205. \\ ${ }^{b}$ Department of Environment, Ministry of Environment and Forest, Dhaka-1207, Bangladesh
}

\begin{abstract}
Dhaka City has been affecting with severe air pollution particularly by particulate matter. The ambient air quality data for particulate matter were collected during April 2002 to September 2005 at the Continuous Air Quality Monitoring Station (CAMS) located at Sangshad Bhaban, Dhaka. Data reveal that the pollution from particulate matter greatly varies with climatic condition. While the level comes down the limit value in the monsoon period (April-October), it goes beyond the limit during non-monsoon time (November-March). The latest data show that during monsoon period PM 10 concentration varies from $50 \mu \mathrm{g} / \mathrm{m}^{3}$ to $80 \mu \mathrm{g} / \mathrm{m}^{3}$ and PM 2.5 concentration from $20 \mu \mathrm{g} / \mathrm{m}^{3}$ to $60 \mu \mathrm{g} / \mathrm{m}^{3}$ and during non monsoon period PM 10 varies from $100 \mu \mathrm{g} / \mathrm{m}^{3}$ to $250 \mu \mathrm{g} / \mathrm{m}^{3}$ and PM 2.5 varies from $70 \mu \mathrm{g} / \mathrm{m}^{3}$ to $165 \mu \mathrm{g} / \mathrm{m}^{3}$. The seasonal variation clearly indicates the severe PM 10 pollution during the dry winter season and also sometime during post-monsoon season in Dhaka City.
\end{abstract}

Keywords: Air pollution, PM 2.5, PM 10, Air quality

\section{Introduction}

Dhaka, the capital of Bangladesh, where more than 12 million people live within $400 \mathrm{~km}^{2}$ is one of the most densely populated cities in the world and facing a high level of air pollution. High influx of people from rural areas, emissions from various kinds of diesel vehicles and badly maintained automobiles, biomass/coal burning for cooking and in the brick kilns, huge number of construction works, re-suspended road dust etc. are making Dhaka as one of the most polluted cities in the world. According to a recent World Bank Report, it has been estimated that every year in the Dhaka City around 10,800 premature deaths along with several million cases of illness are being caused by the air pollution. The economic cost of this sickness and deaths is estimated to be \$132 - \$583 million per year for Dhaka (Brandon C., 1997).

This high level of air pollution and its economic cost demands a comprehensive air quality management plan to improve the air quality of Dhaka City. The urban air quality management plan usually consists of four important components and these are: (i) air quality monitoring, (ii) emission inventories, (iii) air quality modeling, and (iv) control strategy development. An effective air quality management for any urban area can only be achieved through a comprehensive approach built upon these key areas.

\footnotetext{
* Corresponding author: E-mail: : roufmd@yahoo.com
}

In Dhaka City, the Air Quality Management Project (AQMP), Department of Environment is carrying out air quality monitoring program at the Continuous Air Monitoring Station (CAMS) in the national parliament house premises since 2002. Moreover, AQMP is also conducting Satellite Air Monitoring Station (SAMS) at four different places in the city. Concentration of PM 10 (particles, which are less than 10 micrometers in diameter) and PM 2.5 (particles, which are less than 2.5 micrometers in diameter) are measured at all of these stations. Monitoring results of PM 10 and PM 2.5 at these stations are available now. Several studies have shown that both the particle size has the significant negative impact on human health (Dockery et. al., 1993, Dockery et. al., 1989). The monitoring activities and results of these harmful particulate matter along with other gaseous pollutant should be disseminate to the general public as well as policy makers to identify the areas where the ambient air quality standards are being violated and plans are needed to reduce pollutant concentration levels to be in attainment with the standards.

Motorized transports are suspected to be the single largest contributor of air pollution in Dhaka, with annual vehicular growth rate of about 7 to $10 \%$ in last ten years. The phase- 
out of two - stroke three wheeler baby taxis in January 2003 resulted in significant air quality improvement in Dhaka City. The decrease in the average PM 10 and PM 2.5 levels for the week after the ban were found to be $31 \%$ and $41 \%$, respectively from the week before ban. The decline in the hydrocarbon was even higher than 50\%. The decline in $\mathrm{CO}$ was about 28\% (AQMP report, 2005).

Overall it was estimated that the impact of the ban translated to about $24 \mathrm{~g} / \mathrm{m}^{3}$ decrease in PM10 in Dhaka on yearly basis. Impact of banning of two-stroke engine of airborne particulate matter concentrations in Dhaka has been studied (Begum et. al., 2006). However, the phase-out of baby taxis led to a void in the public transport infrastructure for some time, resulting in a sudden influx of a large number of polluting vehicles, such as mini buses, maxi and humanehaulers. The number of such vehicle has been grown significantly since then (including the addition of number of new buses, some of which are run by $\mathrm{CNG}$ ), with the result that there is not enough road space for all the motor vehicles in the city resulting traffic congestion. It is well documented that such traffic conditions lead to higher emissions from motor vehicles compared to smooth flow of traffic. Recent data from Continuous Air Quality Monitoring Station (CAMS) show that air quality of Dhaka City is worsening, hence undoing some of the gains of the baby taxi phase-out. There is an urgent need to ensure that the growth in vehicular traffic and transport infrastructure in Dhaka is environmentally sound and sustainable. It has become essential to formulate policy option to tackle the problem of gross polluting diesel vehicle, with a view to arresting and possibly reversing the deteriorating trend in air quality.

Diesel engine emissions are now the major source of PM and therefore significant improvements in air quality will only be realized through diesel engine emission control. Recent emission inventory analysis shows that more than $80 \%$ of PM pollution in the transport sector comes from diesel vehicle. Particularly, in winter particulate matter remains a major public health threat in Dhaka City with concentration level (24-average) exceeding standards by two and a half times occasionally.

Investigation of sources of atmospheric aerosol at urban and semi-urban areas in Bangladesh has been studied (Begum et. al. 2004). Begum et. al. (2003) has also made a study on Investigation of sources of atmospheric aerosol at a hot spot area in Dhaka, Bangladesh.
A high concentration of air pollutants such as black carbon in Dhaka City has been reported (Salam et. al., 2003). Vehicular emissions, as well as biomass/coal burning for cooking and in the brick kilns around the city, are the main contributor to these emissions (Chaloulakou et. al., 1999; Kassomenos et. al., 1995). Not much work has been done on air quality of Dhaka City. The following are the objective of this research work:

1. To find out seasonal variation of concentration of PM 10 and PM 2.5 in Dhaka City in order to understand its health impact.

2. To evaluate the relation between PM 10 and PM 2.5 concentration.

\section{Material Method}

\section{Particulate matter Sampling}

Particulate matter (both PM 10 and PM 2.5) samples are collected with Federal Reference Method Samplers. The PM size fractionation in the samplers is mainly achieved by impaction technique. The air enters the unit through a stage designed to have $50 \%$ collection efficiency at $10 \mathrm{~m}$ equivalent aerodynamic diameters (EAD) for PM 10 samplers and $2.5 \mu \mathrm{m}$ EAD for PM 2.5 samplers.

\section{PM 10 and PM 2.5 Samplers}

The air samplers operate on the same principle. They draw ambient air at a constant flow rate into a specially shaped inlet where the suspended particulate matter is initially separated into one or more size fractions within the size range as indicated by the name of the sampler, i.e PM 10 size range for PM 10 sampler and PM 2.5 size range for PM 2.5 sampler. Each size fraction is then collected on a glass fiber filter over the sampling period of $24 \mathrm{~h}$. Each filter is weighed (after moisture equilibration) before and after use to determine the net weight gain due to collected particular matter in the range. The total volume of air sampled, measured at the actual ambient temperature and pressure, is determined from the measured flow rate and the sampling time. The mass concentration of that type of particular matter in the ambient air is computed as the total mass of collected particles in the size range divided by the volume of air sampled, and is expressed in microgram per actual cubic meter $\left(\mu \mathrm{g} / \mathrm{m}^{3}\right)$. 
Table I: Monthly average PM10 and PM2.5 with standard deviation

\begin{tabular}{|c|c|c|c|c|}
\hline \multirow[t]{2}{*}{ Month } & \multicolumn{2}{|c|}{ PM $10\left(\mu \mathrm{g} / \mathrm{m}^{3}\right)$} & \multicolumn{2}{|c|}{ PM $2.5\left(\mu \mathrm{g} / \mathrm{m}^{3}\right)$} \\
\hline & Average & Standard deviation & Average & Standard deviation \\
\hline April'02 & 91 & \pm 18 & 44 & \pm 15 \\
\hline May'02 & 87 & \pm 18 & 42 & \pm 11 \\
\hline June'02 & 56 & \pm 17 & 23 & \pm 8 \\
\hline July'02 & 88 & \pm 33 & 32 & \pm 12 \\
\hline August'02 & 66 & \pm 17 & 28 & \pm 7 \\
\hline September'02 & 64 & \pm 33 & 33 & \pm 18 \\
\hline October'02 & 131 & \pm 44 & 90 & \pm 37 \\
\hline November'02 & 161 & \pm 66 & 138 & \pm 74 \\
\hline December'02 & 252 & \pm 94 & 192 & \pm 48 \\
\hline January'03 & 271 & \pm 98 & 196 & \pm 89 \\
\hline February'03 & 244 & \pm 77 & 151 & \pm 57 \\
\hline March'03 & 202 & \pm 105 & 88 & \pm 35 \\
\hline April'03 & 104 & \pm 31 & 46 & \pm 18 \\
\hline May'03 & 97 & \pm 29 & 36 & \pm 11 \\
\hline June'03 & 68 & \pm 31 & 27 & \pm 9 \\
\hline July'03 & 46 & \pm 9 & 19 & \pm 5 \\
\hline August'03 & 50 & \pm 13 & 23 & \pm 7 \\
\hline September'03 & 65 & \pm 18 & 35 & \pm 12 \\
\hline October'03 & 93 & \pm 39 & 59 & \pm 26 \\
\hline November'03 & 183 & \pm 52 & 117 & \pm 43 \\
\hline December'03 & 168 & \pm 47 & 108 & \pm 35 \\
\hline January'04 & 192 & \pm 81 & 130 & \pm 51 \\
\hline February'04 & 236 & \pm 69 & 119 & \pm 30 \\
\hline March'04 & 165 & \pm 75 & 103 & \pm 20 \\
\hline April'04 & 104 & \pm 38 & 104 & DNA \\
\hline May'04 & 103 & \pm 37 & 50 & +21 \\
\hline June'04 & 69 & \pm 14 & 29 & \pm 5 \\
\hline July'04 & 55 & \pm 12 & DNA & - \\
\hline August'04 & 54 & \pm 8 & DNA & - \\
\hline September'04 & 66 & \pm 34 & DNA & - \\
\hline October'04 & 112 & \pm 57 & 70 & \pm 15 \\
\hline November'04 & 184 & \pm 45 & 121 & +40 \\
\hline December'04 & 248 & \pm 42 & 136 & +48 \\
\hline January'05 & 250 & \pm 80 & 166 & \pm 70 \\
\hline February'05 & 205 & \pm 57 & 115 & \pm 62 \\
\hline March'05 & 142 & \pm 35 & 101 & \pm 35 \\
\hline April'05 & 124 & \pm 70 & 83 & \pm 50 \\
\hline May'05 & 83 & \pm 15 & 36 & \pm 13 \\
\hline June'05 & 70 & \pm 25 & 27 & \pm 13 \\
\hline July'05 & 47 & \pm 18 & 22 & \pm 10 \\
\hline August'05 & 51 & \pm 15 & 27 & \pm 11 \\
\hline September'05 & 61 & \pm 28 & 38 & \pm 18 \\
\hline
\end{tabular}




\section{Results and Discussions}

\section{Daily means}

Figure 1 and 2 reveal the annual variation of daily averaged PM 10 and PM 2.5 concentrations against the proposed 24hour average standard. From these two figures it can be seen that the 24-hour average PM concentrations were followed a clear systematic cycle throughout the whole monitoring period. In the dry winter season (November to February) the PM concentrations were exceeded the standard almost everyday. PM concentrations were started to decrease from March as rainfall starts. In the rainy season the concentration of PM became less than the standard and again started to increase from October. During the dry season the day-to-day variation of PM concentrations were higher than in rainy season.

\section{Monthly variation and annual average}

Table I lists the monthly average PM 10 and PM 2.5 concentrations and their standard deviation from April 2002 to December 2005. From this table it can be seen that almost all of the months in a year, the PM concentrations exceed the annual average standard (PM 10- $50 \mu \mathrm{g} / \mathrm{m}^{3}$, PM 2.5- 15 $\left.\mu \mathrm{g} / \mathrm{m}^{3}\right)$. Even monthly average of concentrations in dry months exceed the 24-hour average standard PM 10- 150 $\mathrm{g} / \mathrm{m}^{3}$, PM 2.5- $65 \mu \mathrm{g} / \mathrm{m}^{3}$ (Dhaka City State of Environment 2005). Monthly average of rainy months was lower than the 24-hour standard whereas exceeded the annual average standard. During dry months the standard deviations were higher than rainy months, which reveals that the day-to-day variation were higher in the dry season than rainy season. Annual arithmetic mean of PM 10 and PM 2.5 in Dhaka City

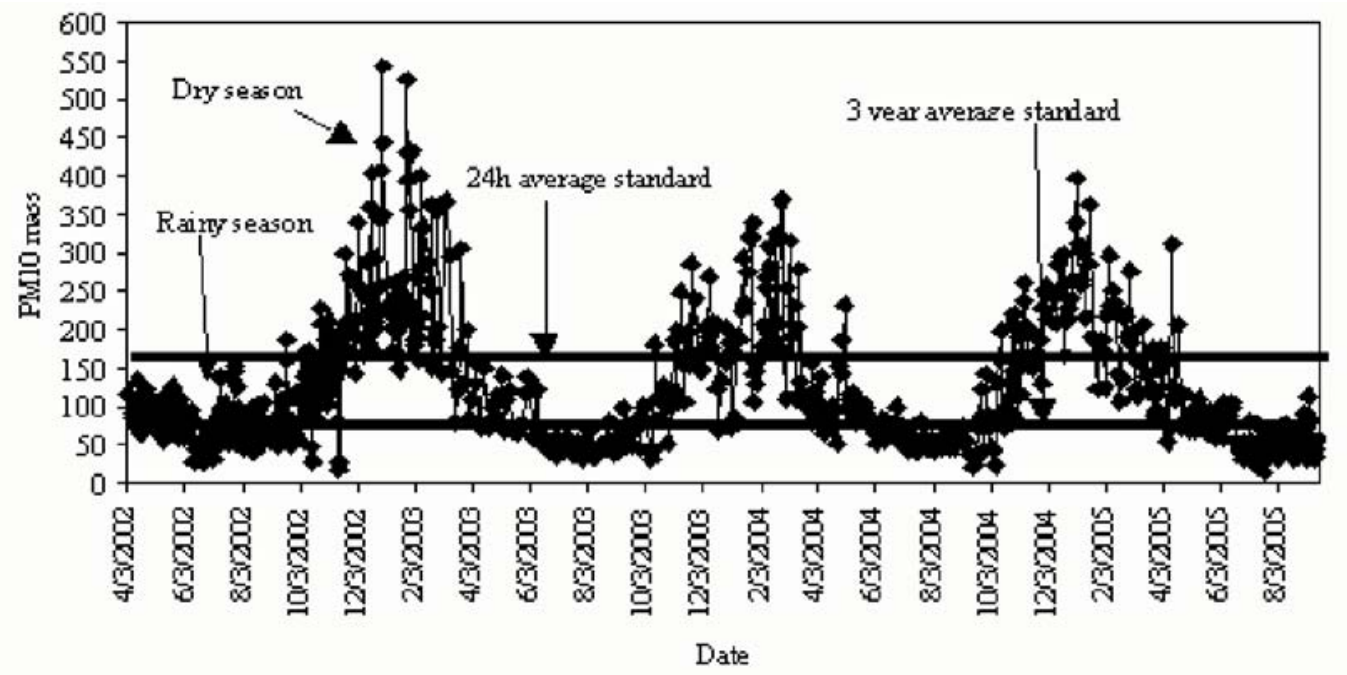

Fig 1: Day to day variation of daily PM10 concentrations in micrograms per cubic meter in Dhaka

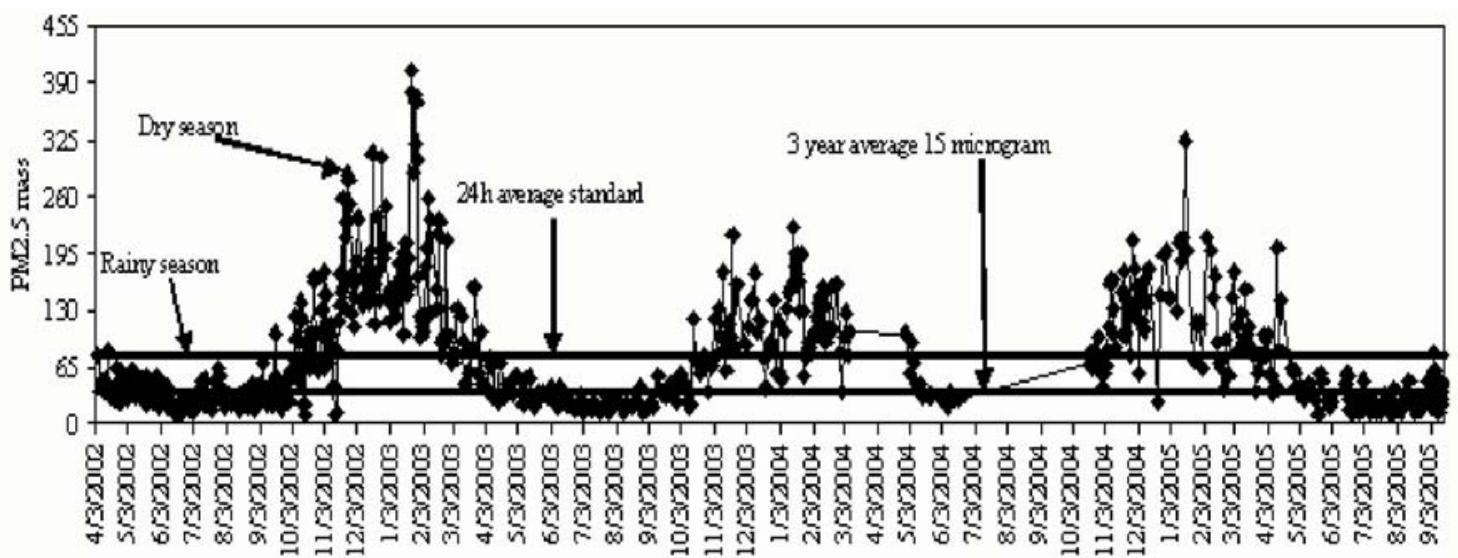

Date

Fig 2: Day to day variation of daily PM 2.5 concentrations in micrograms per cubic meter in Dhaka 
is shown in figure 3. No significant variation of PM 10 and PM 2.5 annual average concentration was observed in the period 2002 to 2005 . with the standard value of PM 10 and PM 2.5 to see how frequently the ambient PM concentration exceeds the threshold value. Exceedances were categorized also according to the

口PMIO aPMD 5

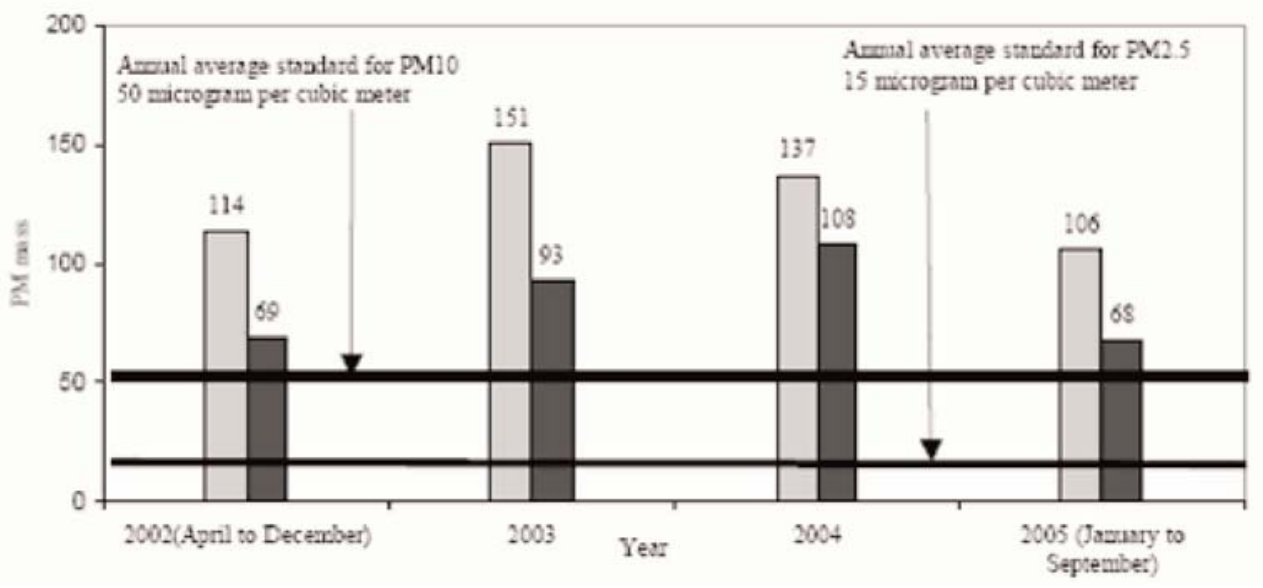

Fig. 3: Annual arithmetic mean of PM 10 and PM 2.5 in micrograms per cubic meter in Dhaka City

\section{Exceedance of standards}

The basis of judging the health impact of PM pollution is the standard value of particulate matter. So it is very important to compare the ambient PM 10 and PM 2.5 concentration four main seasons. Figure 4 shows that dry winter season was the most vulnerable season when more than $90 \%$ of monitoring days exceeded the threshold value for both PM 10 and PM 2.5. 46\% days of PM 10 and 78\% of PM 2.5 were

\section{口FNIOAFWE}

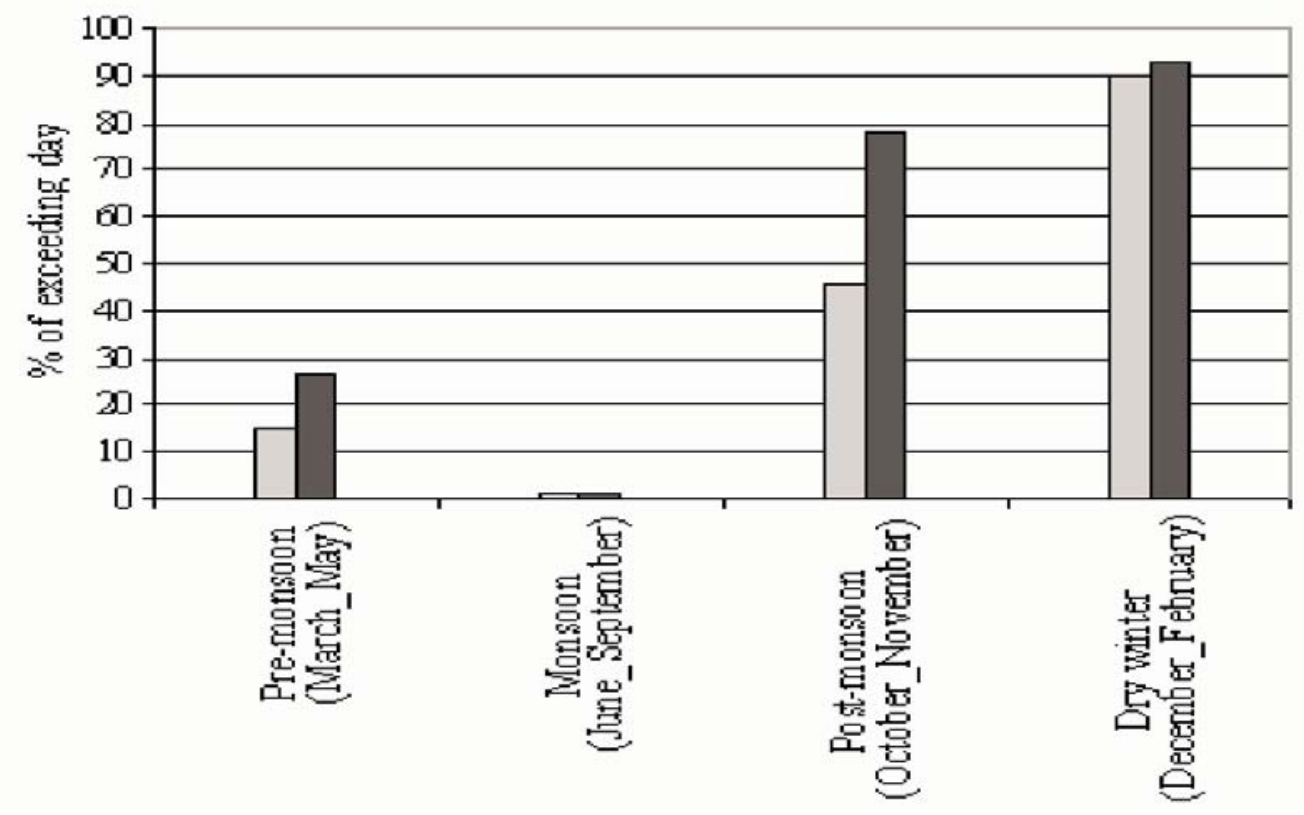

Fig 4: Seasonal \% of exceedance of PM monitoring days in Dhaka City 
exceeded during post-monsoon season followed by $15 \%$ and $27 \%$ in pre-monsoon season respectively. Exceedances were hardly found during monsoon.

\section{Weekday and weekend effect on PM concentration}

Weekday and weekend effect due to traffic and some industrial activities can lead to a variation in PM concentrations in similar weather conditions. In this section, it was intended to analyze the concentration of particulate matter by day of week in Dhaka and to describe or characterize any weekday/weekend effect on particulate matter. Figure 5 shows the effect of weekday/weekend on PM concentration by day of week in Dhaka. No significant trend was observed when the concentrations of PM 10 and PM 2.5 on weekdays were compared with the weekend concentrations as shown in figure 6. Previous studies showed that the traffic is the main source of particulate matter in Dhaka. In general, it is observed that the traffic volume substantially decreases dur

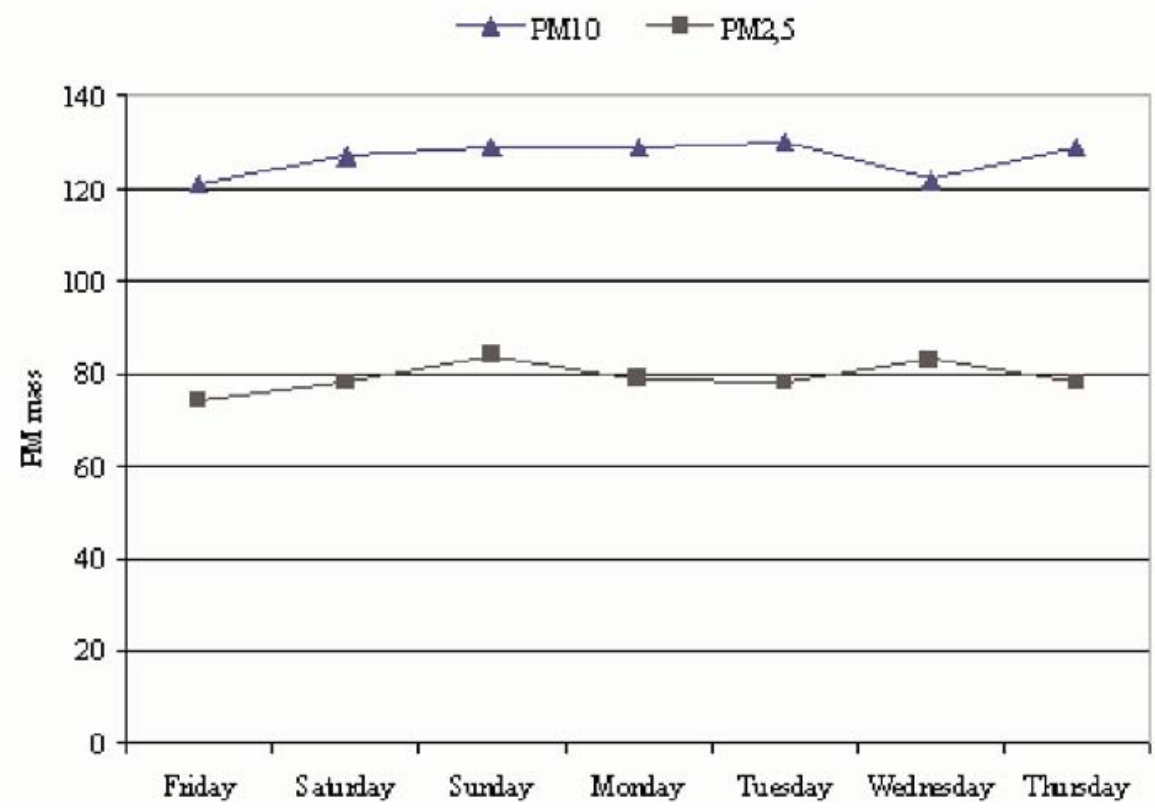

Fig 5: Variation of PM concentration in micrograms per cubic meter by day of week in Dhaka City

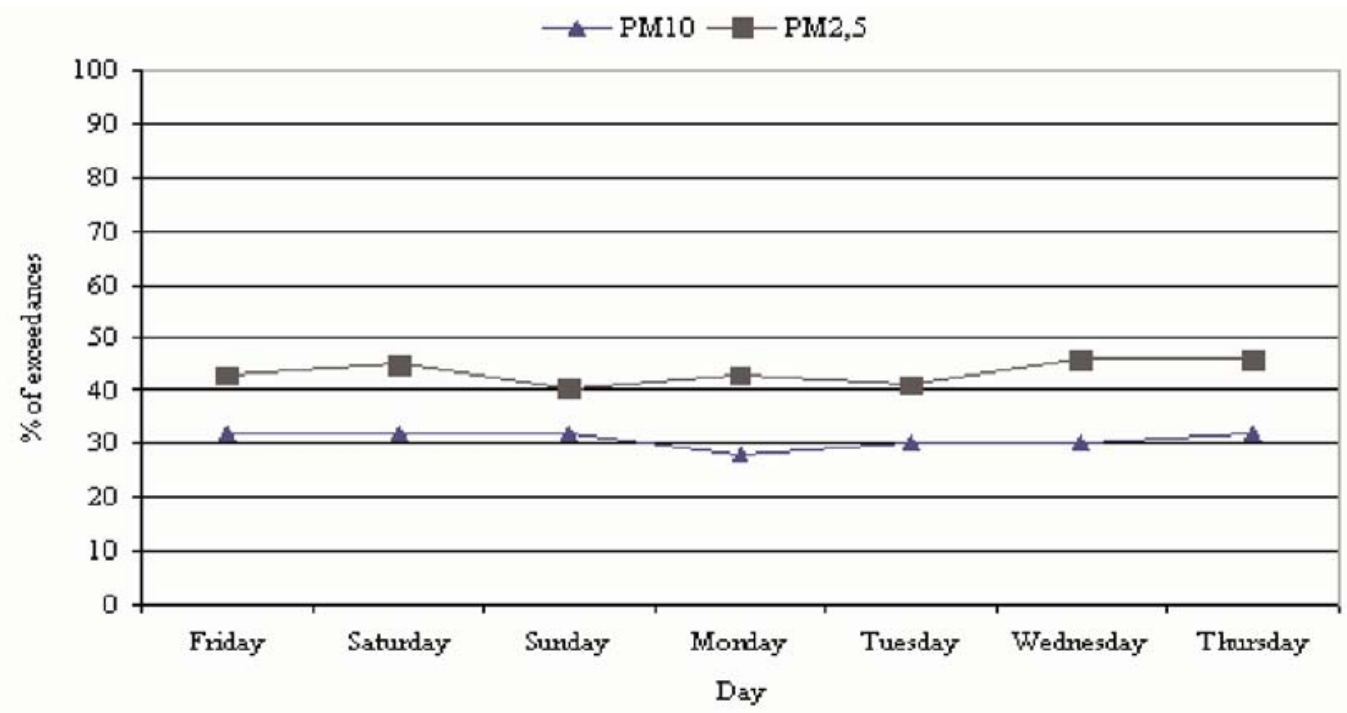

Fig. 6: Variation of PM exceedances by day of week in Dhaka City 
ing holidays in Dhaka City. It was expected that weekends should have less PM concentration than weekdays. This may have happened as a result of ignoring the seasonal effect when the weekday and weekend averages were calculated. But previous plots showed that there is a great seasonal influence on the concentration of particulate matter in Dhaka City. The monitoring location is not adjacent to the roadways that may be another reason. One important fact is supported by this characteristic is that the chemical analysis of particu

\section{Relation between PM 10 and PM 2.5}

The relationship between PM 2.5 and PM 10 levels were analyzed in this report as well as the mass ratio of them. Figure 7 showed that daily concentration of PM 10 and PM 2.5 are strongly correlated $\left(r^{2}=0.82\right)$, which reinforces the strong relationship between PM 2.5 and PM 10 in Dhaka. To evaluate the consistency of PM 2.5 and PM 10 mass measurements, the mass ratios were calculated for the whole monitoring period to ensure that PM 2.5 mass did not exceed

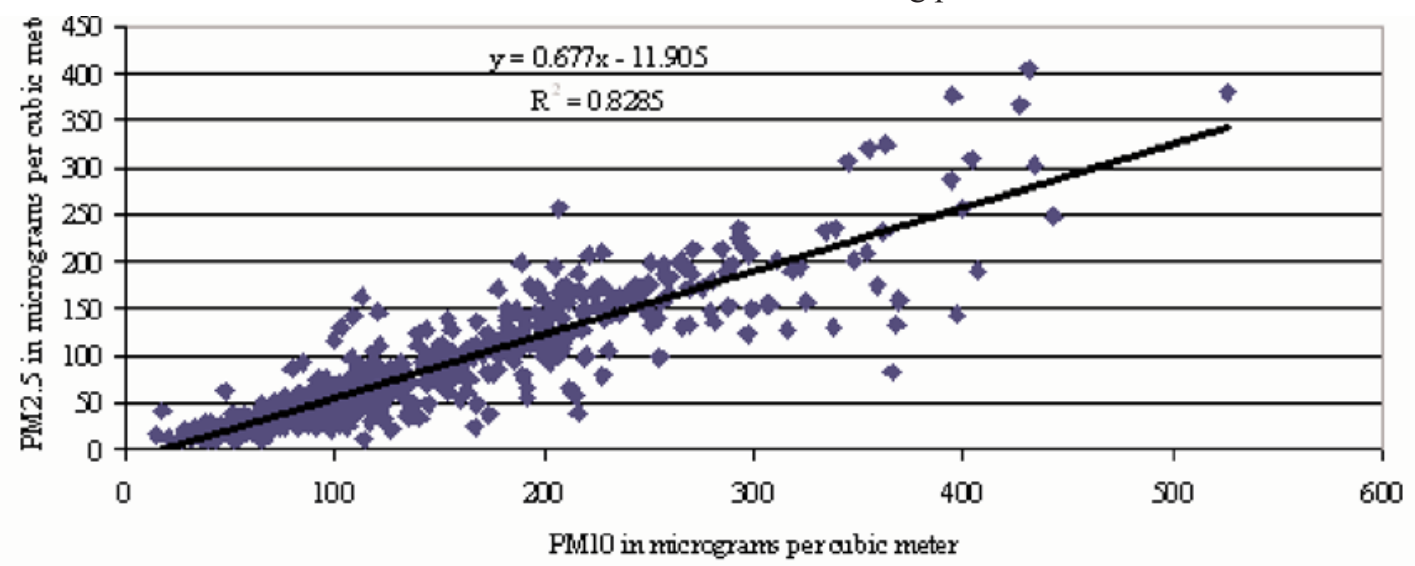

Fig. 7: Scatter plot of 24-hour PM 10 and PM 2.5 in Dhaka City

late matter has shown that the type of particulate matter in Dhaka is secondary (Mahbubul Islam, 2005). That's why the PM concentration does not reduce immediately after the suspension of its main sources. However, we can also assume that the concentration of particulate matter of Dhaka is more dependent on meteorological condition than the emissionsource itself.
PM10 mass. Figure 8 shows the mass ratio between PM 10 and PM 2.5 in Dhaka for the whole monitoring period and the average mass ratio between PM 10 and PM 2.5 was calculated to be 0.55 .

Several studies on mass ratio of PM 10 and PM 2.5 for some other cities have shown that the average ratio varies between

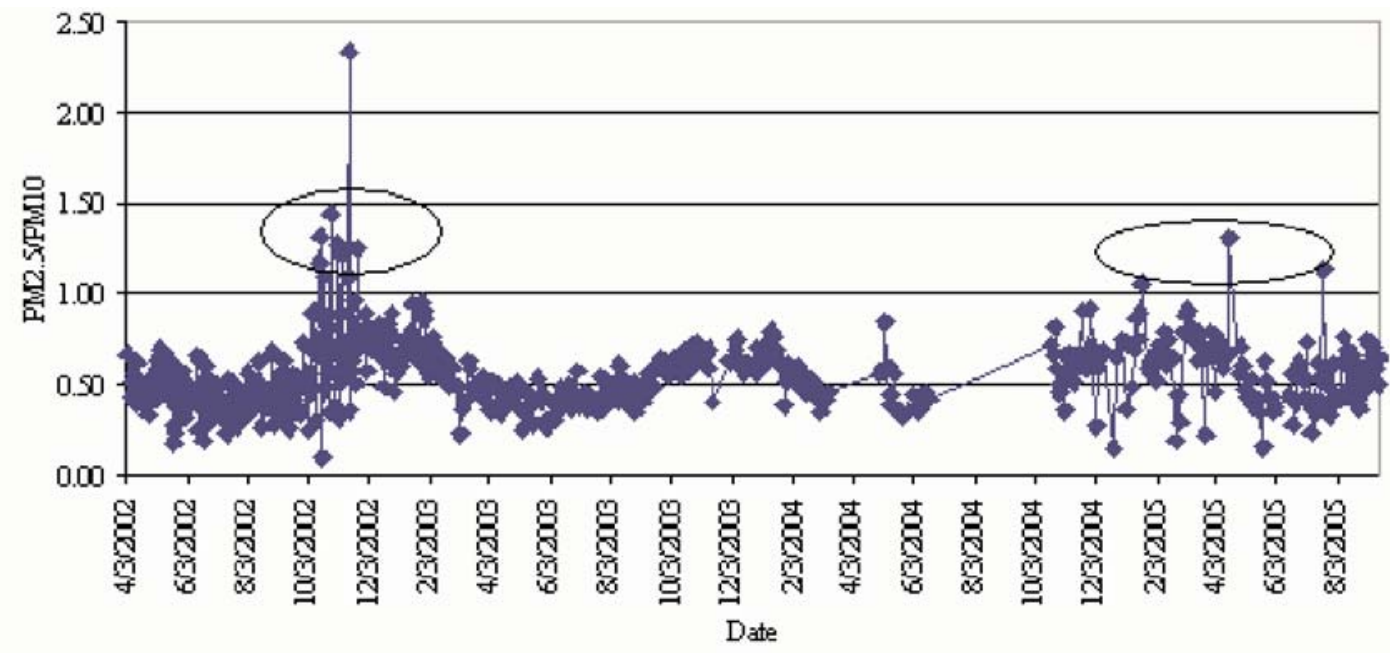

Fig. 8: Mass ratio of PM 2.5 to PM10 in Dhaka City 
0.4 to 0.8 and depends on some factors that vary spatially and temporally (Bogo et al., 2003, Chaloulakou et al., 2003, Cheng et al., 1998, Ruellen et al., 2001, Harrrison et al., 1997, Slavica et al., 2004). It is clear from the plot that the ratio maintained a systematic trend between season to season over the monitoring period. Table II presents the mass ratio in different seasons. The ratio was highest during post-monsoon season $(0.70)$ followed by dry winter season $(0.64)$. The lowest ratio during monsoon season $(0.45)$ clearly indicates that the meteorological factors influence the ratio between PM 10 and PM 2.5 in Dhaka.

Table II: PM 2.5/PM 10 ratio in different seasons

\begin{tabular}{l|c|c}
\hline Season & $\begin{array}{c}\text { PM2.5/ } \\
\text { PM10 }\end{array}$ & $\begin{array}{c}\text { Standard } \\
\text { deviation }\end{array}$ \\
\hline Dry winter (December to February) & 0.64 & \pm 0.14 \\
Pre-monsoon (March to May) & 0.51 & \pm 0.16 \\
Monsoon (June to September) & 0.45 & \pm 0.12 \\
Post-monsoon (October to November) & 0.70 & \pm 0.28 \\
Whole monitoring period & & \\
(April 2002 to September 2005) & 0.55 & \pm 0.19 \\
\hline
\end{tabular}

Figure 9 clearly shows that the PM2.5 mass fraction decreases during rainy months and increases during dry winter months. Previous studies for other cities also support this fact (Bogo et al., 2003, Chaloulakou et al., 2003, Cheng et al., 1998, Ruellen et al., 2001, Harrrison et al., 1997, Slavica et al., 2004). High concentrations of particulate matter usually result from a combination of primary and secondary contributions. Primary particles are directly emitted from sources, while secondary particles form in the atmosphere by chemical reaction of different gaseous pollutants e.g., sulfur dioxide, oxides of nitrogen, ammonia etc. Usually the secondary particulate matter forms under stagnant air conditions during winter time due to poor dispersion of emission from ground level sources. The life time of this secondary PM 2.5 is high and contributing high proportion of mass in to PM 10, which also indicate that a significant part of particulate matter in Dhaka is secondary particulate. A previous chemical speciation study of particulate pollution in Dhaka identified the contribution of secondary aerosol in particulate matter (Mahbubul Islam, 2005). From figure 8 it can be seen that some of the data points (circled) of mass ratio were more than one i.e., PM2.5 mass exceeded the PM 10 mass which is theoretically impossible as PM 2.5 belongs to PM 10. The mass of PM 2.5 can never exceed the mass of PM 2.5. This may be due to measurement error or some other instrumental faults.

From the above analysis it is clear that the concentration of particulate matter, its variation, exceedances, mass ratio between PM 10 and PM 2.5 in Dhaka are greatly variable depending on season.

\section{Conclusion}

Dhaka City is affected with severe air pollution where particulate matter is being identified as the main pollutant of concern. Data from the monitoring station reveals that the pollution from particulate matters greatly varies with climatic conditions. While the level comes down the limit value in the monsoon period (April-October), it goes beyond the limit

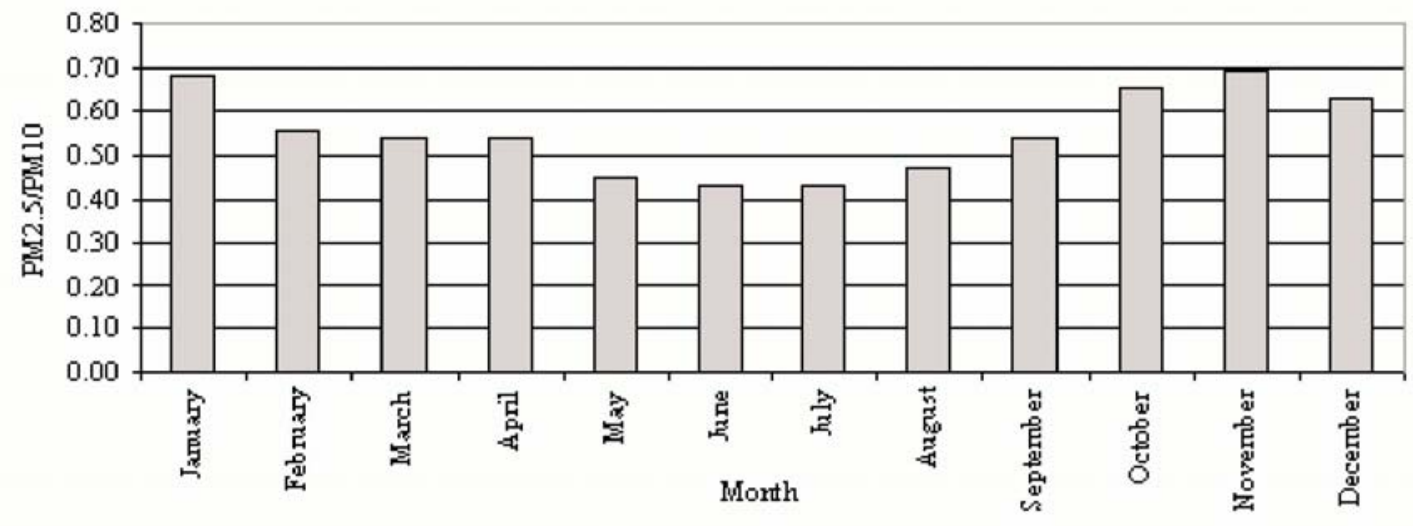

Fig. 9: Monthly average PM 2.5/PM 10 ratio in Dhaka 
during non-monsoon time (November-March). The extent of pollution level during non monsoon period was found much higher than the standard level indicating alarming threat to the human heath. Government's decision to ban on two stroke engines and to pull out old buses and trucks from the city improved air quality significantly. But the recent data shows the trend again going upward; perhaps due to sudden increase of large number of diesel vehicles entered the city to minimize the transport vacancies. The latest data shows that during monsoon period PM 10 concentration varies from $50 \mu \mathrm{g} / \mathrm{m}^{3}$ to $80 \mu \mathrm{g} / \mathrm{m}^{3}$ and PM 2.5 concentration from $20 \mu \mathrm{g} / \mathrm{m}^{3}$ to $60 \mu \mathrm{g} / \mathrm{m}^{3}$ and during non monsoon period PM 10 varies from $100 \mu \mathrm{g} / \mathrm{m}^{3}$ to $250 \mu \mathrm{g} / \mathrm{m}^{3}$ and PM 2.5 varies from $70 \mu \mathrm{g} / \mathrm{m}^{3}$ to $165 \mu \mathrm{g} / \mathrm{m}^{3}$. The seasonal variation clearly indicates that the severe PM 10 pollution during the dry winter season and also sometime during post-monsoon season in Dhaka City. Emission from vehicles, domestic cooking, industries, and building construction material and road dust are the main sources of pollution. Sometimes in winter the particulate matter exceeds two to three times more than 24hours average standard value. It is necessary to set up more CAMS in the city, so that air quality of the city can be monitored at different location precisely. Particulate matter concentration may be significantly reduced by taking brick field far away from the city and covering uncovered road. It is also necessary to remove all old vehicles from the city for improving the air quality.

\section{References}

Anon (2005). Report on public opinion survey: Black smoke emission from diesel vehicles in Dhaka City, Air Quality Management Project, Department of Environment, Sher-e-Bangla Nagar, Dhaka-1207. Page-1

Begum B. A., Kim E., Biswas S. K. and Hopke P. K. (2006). Impact of banning two-stroke engine on airborne particulate matter concentrations in Dhaka, Bangladesh. $J$. Air Waste Manage. Asso., 56: 85-89.

Begum B. A., Biswas S. K., Kim E., Hopke P. K. and Khaliquzzaman M. (2005). Investigation on sources of atmospheric aerosol at a hot spot area in Dhaka, Bangladesh. J. Air Waste Manage. Asso., 55: 227-240.
Begum B. A., Kim E., Biswas S. K. and Hopke P. K. (2004). Investigation on sources of atmospheric aerosol at urban and semi-urban areas in Bangladesh. Atmos. Environ., 38: 3025-3038.

Bogo H., Otero M., Castro P., Ozafran M., Kreiner A., Calvo E. and Negri M. (2003). Study of atmospheric particulate matter in Buenos Aires city. Atmos. Environ., 37: $1135-1147$

Brandon C. (1997). Economic valuation of air and water pollution in Bangladesh. Workshop Discussion Draft, The World Bank, Washington D. C.

Chaloulakou A., Kassomenos P., Spyrellis N., Demokritou P. and Koutrakis P. (2003). Measurements of PM 10 and PM 2.5 particle concentrations in Athens, Greece. Atmos. Environ., 37: 649-660.

Cheloulakou A., Assimacopoulos D. and Lekkas T. (1999). Daily maximum O3 concentrations in the Atherns Basin. Environ. Monit. Assess., 56: 2559-67.

Cheng S. and Lam K. (1998). An analysis of winds affecting air pollution concentrations in Hong Kong. Atmos. Environ., 32: 2559-2567.

Dhaka City State of Environment (2005). Department of Environment Ministry of Environment and forest government of the People Republic of Bangladesh in collaboration with United Nations Environmental Programme Regional Resource Centre for Asia and the Pacefic (UNEP RRCAP) and Bangladesh Centre for Advance Studies. Page-32

Dockery D. W., Pope C. A., Xu X. P., Spengler J. D., Ware J. H., Fay M. E., Ferris B. G. and Speizer F. E. (1993) An association between air pollution and mortality in six U. S. cities. New England Journal of Medicine, 329: 1753-1759.

Dockery D. W., Speizer F. E., Stram D. O., Ware J. H., Spengler J. D. and Ferris B. G. (1989). Effects of inhalable particles on respiratory health of children. Am. Rev. Respir. Dis., 139(3): 587-594.

Harrison R. M., Deacon A. R., Jones M. R. and Appleby R. S. (1997). Sources and processes affecting concentra- 
tions of PM10 and PM2.5 particulate matter in Birmingham (UK). Atmos. Environ., 31: 4103-4117.

Kassomenos P., Kotroni V. and Kallos G. (1995) Analysis of climatological and air quality observations from greater Athens area. Atmos Environ., 29B: 3671- 3688.

Islam M. (2005). Senior Environmental Scientist, USEPA, Chemical Specification of Particulate Matter Pollution in Urban Dhaka City, Personal communication.

Ruellan S. and Cachier H. (2001). Characterization of fresh particulate vehicular exhausts near a Paris high flow road. Atmos. Environ., 35: 453-468.
Salam A., Bauer H., Kassin K., Ullah S. M. and Puxbaum H. (2003). Aerosol chemical characteristics of a mega-city in Southeast Asia (Dhaka, Bangladesh). Atmos. Environ., 37: 2517-28.

Slavica F. R., Mirjana D. T., Velibor T. N. and Milicia N. T. (2004). First assessment of the PM10 and PM2.5 particulate level in the ambient air of Belgrade city. Environ. Sci. Pollu. Res., 11: 158-164.

Received :June 08, 2010

Accepted : January 04, 2011 